
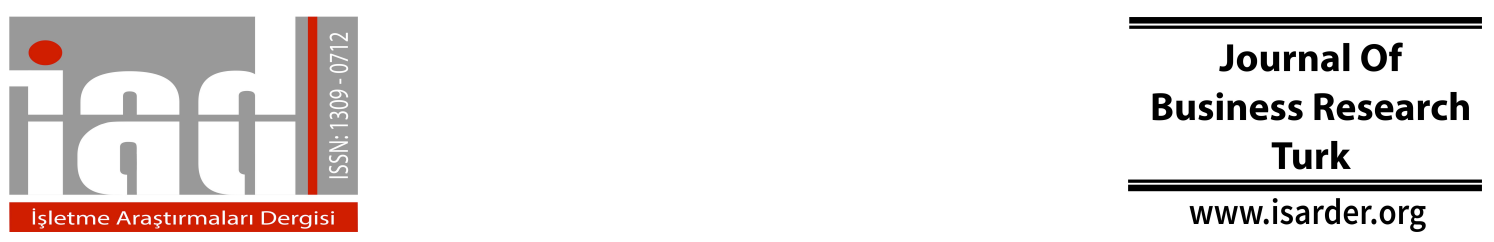

\title{
An Exploration of Hospitality Management Competencies in Turkey through Content Analysis of the Job Ads
}

\author{
Rahman TEMIZKAN \\ Eskisehir Osmangazi University \\ Faculty of Tourism \\ Department of Travel Management and \\ Tour Guidance \\ Eskisehir, Turkey \\ orcid.org/0000-0002-9750-1543 \\ rtemizkan@ogu.edu.tr
}

\author{
Orhan YABANCI \\ Eskisehir Osmangazi University \\ Faculty of Tourism \\ Department of Travel Management and \\ Tour Guidance \\ Eskisehir, Turkey \\ orcid.org/0000-0001-5079-5030 \\ oyabanci@,ogu.edu.tr
}

\begin{abstract}
This paper reports on the hospitality management competencies required to be assigned to a management position in Turkey. The study found out a number of competencies with top priority ranging from 82.1 to 21.4 percent extracted from job ads on the most browsed career websites in Turkey by employing a content analysis as the research method. These core competencies were delineated in the five domains of Sandwith's Competency Domain Model in order to discover how they pertained to the theory. The in-depth analysis rendered the whole range of domains particularly leadership, technical and interpersonal, partly conceptual/creative and administrative. The study concluded that recruiters mainly look for managers with leadership, technical and interpersonal competencies in Turkey.
\end{abstract}

Keywords: Hospitality, management, competency, competencies, Turkey, the Competency Domain Model.

\section{Introduction}

Tourism, with its social, cultural, political and various other impacts (Hall, 2005, p.218; Hong, 2008, p.1) is a global phenomenon of our time (Sharpley, 2004, p.11; Edgel et al., 2014, p.1). And as a services industry, it majorly pivots on human resources (Cheng and Brown, 1998, p.136; Cooper et al., 2008, p.364; Baum, 2012, p.124). Today, there is a burgeoning demand on qualified employees by professional tourism organizations (Nickson, 2011, p.142; Wang, Ayres and Huyton, 2009, p.251) in order to get competitive advantage, enhance service quality and ensure customer satisfaction (Pfeffer, 1994, p.16; Nankervis and Debrah, 1995, p.507; Kusluvan and Kusluvan, 2000, p.251). These organizations give a considerable outlay in recruiting employees based on a set of criteria (Lee-Ross and Pryce, 2010, p.39). However, generally speaking, the industry has a bad reputation for work conditions and career opportunities (Baum and Kokkranikal, 2005, p.93; Roney and Oztin, 2007, p.6; Nickson, 2011, p.2). As a consequence, tourism firms face difficulties with acquiring 
and retaining the qualified staff (Liu and Wall, 2006, p.162; Richardson, 2010, p.1). Thus, ceteris paribus, it results in high staff turnover, poor service quality ending with low yearly revenues of the firms and etc. (Becherel and Cooper, 2002, p.2; Jolliffe and Farnsworth, 2003, p.312; Lee-Ross and Pryce, 2010, pp.14-15; Bardarova, Jakovlev and Koteski, 2013, p.75). Further, it affects the sustainable development (University of Cambridge, 2016; Baum, 2012, p.124) on a macro level. Therefore, the need for investing in human resources is essential (Dale and Robinson, 2007, p.56) and reviewing the issue with different aspects of it to ferret out new methods for developing qualified staff is critical.

\section{Problem statement}

Many countries that get income from tourism have problems for acquiring qualified staff to employ in the sector (Liu and Wall, 2006, p.162; Thomas and Agustyn, 2007, p.56; Richardson, 2010, p.1). These countries in order to overcome these problems develop some varying strategies. Perhaps the most comprehensive one of those strategies is the tourism education (Dunne, Bennett and Carre, 1997, p.512; Valachis, 2003, p.2) as today there are enormous numbers of tourism programs from secondary to tertiary education across many of those countries benefitting from the industry (Airey and Johnson, 1999, p.229). The number of these programs escalate per annum (Evans, 1993, p.243; Su, Miller and Shanklin, 1997, p.36; Petrova and Mason, 2004, p.153). However, apropos of the proliferation, dichotomies and discrepancies emerge significantly raising major distinctions in the quality of what is being taught and questions about the righteousness at all in the minds of the recruiters and community (Su, Miller and Shanklin, 1997, p.36; Petrova and Mason, 2004, p.153). As a consequence, managers are not convinced enough that graduates can fit the needs of the industry (Petrova and Mason, 2004, p.153) and tourism education is fiercely criticized for students being not educated on the needs industry precisely requires (Evans, 1993, p.245; Ashley, et al., 1995, p.75; Ladkin, 2005, p.446; Petrova and Mason, 2004, p.153; Tsai, et al., 2006, p.50). As Chung (2000) states that competencies those required in the industry are quite different than those thought in the tourism institutions. Various researchers state the case by the concepts of skills gap, gap or competencies gap that describe the distinction between the skills and competencies that prevailing vacancies require and those candidates already possess (Werner and DeSimone, 2012, p.289; Wang Ayres and Huyton, 2009, p.62; Liu and Wall, 2006, p.162; Petrova and Mason, 2004, p.154; Amoha and Baum, 1997, p.3; Subramonian, 2008, p.45). Overall, the symptoms attest to an outstanding coordination problem between the industry and the academy which suggests a serious impediment for the achievement of quality and sustainability concerning the industry's expectations, HR qualifications and customers' satisfaction trio. To this point, a collaboration between the professionals and academics (Nolan et al., 2010, p.450) and coherence between the teaching and industry's expectations (Okeiyi et al., 1994, p.37) is a critical matter of concern and one of the key issues to focus on is the scrutiny of hospitality management competencies. Thus, this paper majorly quests the salient prevailing competencies that industry claims from the management candidates.

\section{Purpose and value of the paper}

Though the roots founded much earlier (Morris, 1973; Mariampolski et al., 1980; Buergermeister, 1983), from the seminal study of Tas (1988) onwards, many studies on 
hospitality management competencies with their various aspects, yet not ferreted out enough, were carried out up to the very recent. This study, distinctively, (1) aims to discover the current competencies of hotel managers actually demanded by the industry in Turkey. Furthermore, (2) the competencies obtained by the analysis were evaluated on and classified under the five domains of Sandwith's (1993) competency domain model to base them on and comprehend how they pertain to the theory. Thus, the study focuses on two core questions to look at;

(1) What key competencies do recruiters look for when hiring management candidates?

(2) How these competencies correlate with/can be classified by the Competencies Domain Model?

\section{Literature review}

To succeed, differentiate from the competitors and gain customer loyalty in the hospitality industry is much ascribed to the quality of services rather than their pricing (Kandampully and Suhartanto, 2000, p.346; Christou, 2002, p.25). If service quality (Christou, 2002, p.25; Jolliffe and Farnsworth, 2003, p.313) and competitive advantage is gained through people, then skills of those people are of critical concernment (Pfeffer, 1994, p.16). Tourism professionals should be equipped with knowledge, skills and abilities (KSAs) to cope with challenges and success in their work environment (Kay and Morkarz, 2004, p.285). This is a key constituent in attaining competitive advantage (Lepak and Snell, 1999, p.35). Firms that employ people with skills which industry needs gain advantage for sustainable (Ployhart and Moliterno, 2011, p.127) competitiveness (Auw, 2009, p.26). A competitive advantage occurs 'when a firm is implementing a value creating strategy not simultaneously being implemented by any current or potential competitors' (Wright et al., 1994, p.303).

Growing globalization, and demands of the global market create an apparent oppress on the core staff of firms to be equipped with the critical competencies as to be able to work in diverse cultural environments (Nolan et al., 2010 p.436). As regards that, formal education is of pivotal concernment (Valachis, 2003, p.2; Nolan et al., 2010, p.433; Dunne et al., 1997, p.512). An effective formal education is assumed to be a great means to raise qualified staff implicit in service quality ending in sound customer satisfaction (Christou, 1999, p.683; Christou and Eaton, 2000, p.1058; Cooper and Shepherd, 1997, p.35). Recruiters and educators are the two major actors in acquiring a fruitful education (Cooper and Shepherd, 1997, p.34; Baum, 1990, p.13). These two actors are expected to collaborate (Cooper and Shepherd, 1997, p.47) simultaneously and canonically in order to meet the required HR. Furthermore, the prevalent expectations of recruiters on skills and competencies constitute the basis for tourism and hospitality programs' design (Baum, 1991, p.3). Consequently, academics and undergraduates should be aware of these expectations and these expectations should be included in the education system (Okeiyi, 1994, p.37). This system should meet the expectations of both recruiters and students in terms of the skills set (Raybould and Wilkins, 2004, p.203; Nolan et al., 2010, p.433; Wang, Ayres and Huyton, 2009, p.69; Breiter and Dements, 1996, p.57). The main objective of tourism education is to raise high caliber graduates with their very best fit in the industry (Christou, 2002, p.25). Thus, a guiding perpetually upgraded competencies area (Kay and Russette, 2000, p.54) should be considered to be established for the hospitality management programs in 
order to fulfill the mission. And these competencies could be placed under scrutiny for becoming the communal language of human resources system (Brophy and Kiel, 2002, p.167).

\section{The competency domain model in a nutshell}

The competency domain model was introduced by Sandwith (1993). This model based on Katz's (1955) concept of skills needed by managers in organizations delineates competencies by extending them through a field research into five domains which are (1) conceptual/creative, (2) leadership, (3) interpersonal, (4) administrative and (5) technical. The model predicates that the core activity of managers is to make decisions. This decision-making process consisting of choosing appropriate responses based on perceived factors in a particular activity is dependent on the competencies possessed by the decision-maker outlined in the five domains.

\section{Methods}

The authors believe that in order to find a reasonable answer to the first questing of the study, it would be the best alternative to have a look at the prevailing job ads for management vacancies of hotels as job ads seem to be depicting the recruiters' demands in real terms and real time. Content analysis is one of the most potent and popular analytical methods for investigating and analyzing mass data in systematical terms (Weber, 1990, p.12; Hall and Valentin, 2005, p.239-242). So, content analysis which is also a good technique for analyzing the web sources (Cooper and Schindler, 2014, p.385) was employed as the most convenient research method for this study.

As technology improves and keep influencing peoples' lives career websites have become one of the major sources for job ads. Today, it is obvious that a myriad of unemployed people choose job sites as the main reference for finding a suitable job. Relatively, recruiters prefer these sites as the first choice in hand for finding eligible candidates perhaps in the least efforts and at the minimum costs. As this is the case, the best fit would be to conduct the research among the web sources.

The substantial research was carried out through the top browsed career websites such as kariyer.net, eleman.net, yenibiris.com, secretcv.com and elemanonline.com.tr (Alexa, 2016) between March 1- March 24, 2016, allegedly, the most dealing time during the year for job advertising on the eve of high season of tourism in Turkey. Ads on tourism jobs published on these websites were detected by using the search engine and approximately 3000 ads were saved in electronic version. The saved ads were filtered for a better methodical examination by a set of criteria specified as follows; (1) five or four-star hotel advertisers, (2) ads concerning a management vacancy, (3) ads concerning candidates with tertiary-degrees.

Concerning the criteria above, the 'Required qualifications' sections of a total of 84 residual ads were analyzed and recorded. The items corresponding to the meanings but differing in speeches were classified into the same category. Consequently, a total of 179 items were rendered as a list. 27 of those items were eliminated as the researcher decided that those would not be related to a competency. As it was inappropriate and vacuous to analyze and include the full list of items in the study, aforementioned items were categorized as absolutely essential (100-81), very important (80-61), important (60-41), slightly important (40-21) and unimportant (20-1) adapted from Nelson and Dopson (2001) and Brown (2016). A total of 14 items allocated to a four strata between 
100 and 21 were considered to refer to the key competencies expected from management candidates by the hospitality recruiters. These competencies were then related to and classified to the five domains of Sandwith's (1993) model.

\section{Findings}

Following the steps delineated in the previous section, the outputs of the analysis were rendered shown in the consecutive tables 1 to 5 . Descriptive statistics of the 84 recruiters that looked for management candidates are shown in table 1 . The recruiters namely advertising hotels consisted of 21 four-stars hotels with $25 \%$ and 63 five-stars hotels with $75 \%$.

Table 1: Descriptives of the job ads concerning the recruiters.

\begin{tabular}{lcc}
\hline \multicolumn{1}{c}{ The Recruiters/Advertisers (Hotels) } & Frequencies & Percentages \\
\hline 4 Stars & 21 & 25,0 \\
5 Stars & 63 & 75,0 \\
Total & 84 & 100,0 \\
\hline
\end{tabular}

A collection of vacancies for management positions that were obtained through the analysis are shown in table 2 . As the table indicates that the analysis supplied us with a number of various management positions from executive to middle management level. It is presumed that intrinsic encompassment of a set of varying positions (basically the two levels) could contribute to underpinning of the assessment process for uncovering the core HMCs. The middle management positions evidently dominate.

Table 2: Descriptives of the job ads concerning the vacancies.

\begin{tabular}{lcc}
\hline \multicolumn{1}{c}{ Vacancies for Management Positions } & Frequencies & Percentages \\
\hline Sales & 17 & 20,2 \\
General & 11 & 13,0 \\
Front-desk & 11 & 13,0 \\
House Keeping & 6 & 7,1 \\
Financial Affairs \& Accounting & 6 & 7,1 \\
Human Resources & 3 & 3,6 \\
Operations & 3 & 3,6 \\
Sales \& Marketing & 3 & 3,6 \\
Marketing & 3 & 3,6 \\
Food \& Beverage & 3 & 3,6 \\
Banquet Sales & 2 & 2,4 \\
Restaurant & 2 & 2,4 \\
Yield/Revenue & 2 & 2,4 \\
Fitness Club & 2 & 2,4 \\
Purchasing & 1 & 1,2 \\
Pub & 1 & 1,2 \\
Computing \& Systems & 1 & 1,2 \\
Auditing/Controlling & 1 & 1,2 \\
Pools & 1 & 1,2
\end{tabular}


M.I.C.E.

Health Club

Spa

Cleaning

Nights Management

Total

\begin{tabular}{lc}
1 & 1,2 \\
1 & 1,2 \\
1 & 1,2 \\
1 & 1,2 \\
1 & 1,2 \\
84 & 100,0 \\
\hline
\end{tabular}

The content analysis of required qualifications sections of the inspected job ads resulted in a fourteen-items-list. Items in the list were allocated to five strata. The allocation was made relying on the percentage intervals stated in the previous section. Competencies with the top rates grouped into the four strata from absolutely essential to slightly important are listed sequentially in table 3 . The first item in the table with a 82,1 percent pertains to the stratum of absolutely essential. The second and third ones with a 67,9 percent to the stratum of very important and the ones between four and six with 46,9 or 42,9 percent to the stratum of important. The remainder fall into the stratum of slightly important with a 32,1 percent or less.

Table 3: Competencies obtained through analysis of the job ads.

\begin{tabular}{lccccccc} 
& \multicolumn{3}{c}{$\mathbf{4}$ Stars } & \multicolumn{3}{c}{$\mathbf{5}$ Stars } & \multicolumn{2}{c}{ Total } \\
\multicolumn{1}{c}{ Competencies } & $\mathbf{N}$ & $\mathbf{\%}$ & $\mathbf{N}$ & $\mathbf{\%}$ & $\mathbf{N}$ & $\mathbf{\%}$ \\
\hline $\begin{array}{l}\text { Having both orally and written foreign } \\
\text { language/s skills }\end{array}$ & 15 & 71,4 & 54 & 85,7 & 69 & 82,1 \\
Having both orally and written & & & & & & \\
communication skills & 12 & 57,1 & 45 & 71,4 & 57 & 67,9 \\
Using the MS Office Software competently & 13 & 61,9 & 44 & 69,8 & 57 & 67,9 \\
Being customer-driven & 12 & 57,1 & 27 & 42,9 & 39 & 46,4 \\
Having teamwork skills & 11 & 52,4 & 25 & 39,7 & 36 & 42,9 \\
Having competent interpersonal skills & 9 & 42,9 & 27 & 42,9 & 36 & 42,9 \\
Having financial planning/budgeting skills & 8 & 38,1 & 19 & 30,2 & 27 & 32,1 \\
Having team-managing skills & 9 & 42,9 & 18 & 28,6 & 27 & 32,1 \\
Having reporting skills & 8 & 38,1 & 18 & 28,6 & 26 & 31,0 \\
Having problem-solving skills & 5 & 23,8 & 20 & 31,7 & 25 & 29,8 \\
Having analytical skills & 5 & 23,8 & 19 & 30,2 & 24 & 28,6 \\
Having sales skills & 7 & 33,3 & 13 & 20,6 & 20 & 23,8 \\
Using front-desk equipment and software & 6 & 28,6 & 13 & 20,6 & 19 & 22,6 \\
competently & 3 & 14,3 & 15 & 23,8 & 18 & 21,4 \\
Having IT skills & & & & & &
\end{tabular}

Following the determination process, the competencies in hand were classified to their corresponding domains in terms of the CDM. The output of the subsequent classification is displayed in table 4. It can be inferred from Sandwith (1993) and generally from the literature that many competencies are not confined to a single domain. In fact, many of them correspond inter se and therefore they might be allocated to multiple domains. Apropos of that, more than half of the competencies in the study were allocated to two or three domains as shown in the table. The domains were put in order regarding their presumed consecutive relevance degrees. 
Table 4: Competencies categorized into the five domains of the CDM.

\begin{tabular}{ll}
\hline Competencies & Domains \\
\hline $\begin{array}{l}\text { Having both orally and written foreign } \\
\text { language/s skills }\end{array}$ & Interpersonal, Technical \\
Having both orally and written & \\
communication skills & Interpersonal, Leadership \\
Using the MS Office Software competently & Technical \\
Being customer-driven & Conceptual/Creative, Interpersonal, \\
Having teamwork skills & Leadership \\
Having competent interpersonal skills & Interpersonal, Leadership \\
Having financial planning/budgeting skills & Interpersonal, Leadership \\
Having team-managing skills & Leadership \\
Having reporting skills & Administrative, Technical \\
Having problem-solving skills & Conceptual/Creative, Leadership \\
Having analytical skills & Conceptual/Creative, Leadership \\
Having sales skills & Technical \\
Using front-desk equipment and software & Technical \\
competently & Technical \\
Having IT skills & \\
\hline
\end{tabular}

As major of the competencies in the list have imperceptible borders, it is hard enough to make concrete delineations conforming to the tenets of the CDM and limit them to solitary domain. Thus, competencies such as foreign language skills, communication skills, being customer driven, teamwork skills, interpersonal skills, financial planning/budgeting skills, reporting skills, problem-solving skills and analytical skills were allocated to various domains. On the contrary, competencies like using MS Office Software, team-managing skills, sales skills, using front-desk equipment and software and IT skills were assumed to have more lucid edges hence confined to whether technical or leadership domains.

The sequential order of the competency items regarding the domains draw a complex pattern, perhaps entropy, which prevent any consistent configuration. In an overall manner, some inferences are possible though. It can unequivocally be discerned by the classification of competency items to their closely relevant domains that leadership and technical domains attached to per seven items equally precede the other three domains. Interpersonal domain linking to five and conceptual/creative domain linking to three items subsume into the middle. Administrative domain with its two links fall within the last rank. Consequently, though it might be erratic, it can be inferred that majorly the leadership and technical domains and the remainder somewhat play a role in making a management career that is at least valid for the case.

The findings of this study correspond in some way to various related antecedent studies of hospitality management competencies. For example, technical competencies like using MS Office Software, sales skills, using front desk equipment/software, IT skills and the competency of financial planning/budgeting skills both technical and administrative corresponded to the some competencies which Kay and Morkarz (2004) appointed in their study to some degree. A closer study in form by Millar, Mao and Moreo (2008) were bringing the same issue to the fore. Conceptual domain 
competencies like analytical skills, problem solving, interpersonal domain competencies like written and verbal communication, multiple language skills, working in groups linked to the ones in here. Overall, the competencies uncovered in here approved those many other in the studies of Kay and Russette (2000), Christou (2002), Wang, Ayres and Huyton (2009), Nolan et al. (2010) and etc. discussed throughout the literature. What was distinct their presentations, frameworks, levels of priorities and perhaps being derived from different environments.

\section{Conclusion}

It is generally depicted throughout the literature that there is a common notion of perceptible communal disagreement on hospitality management competencies among the recruiters, educators and candidates. Many papers have already proved that this school of thought has its roots in the actual sentiments of the stakeholders. The discrepancy concerning the competencies among the demands of recruiters, expectations of educators and KSAOs of the candidates, posited as "gap" by the researchers, has led to a rigid uncertainty in tourism education.

As studies on the issue proliferate, many of those prescribe remedies in order to alleviate the unpleasant symptoms of the prevailing system. In the face of various inferences and prescriptions made through, lots of things from the old school still keep going on discrete in practice, not as what fellows expect. Perhaps, one starting point to eliminate these pervasive defects is to open the gateways among the stakeholders for a healthier communication and make a stronger connection inter se.

It is now an unambiguous axiom that competencies owned by staff particularly those in management positions are of critical importance for organizational success and are at the core of high quality in services industries. Firms that hire people with competencies industry requires, in a holistic point of view, remain sustained and keep growing in the long term.

Aside from advocating the findings of various previous studies on the subject conducted throughout different countries, this study have some inferences to make as well. Reminiscing that this study tried to respond to the two questions. Under the lead, a set of prevalent competencies were managed to determine. These competencies, then, were allocated to their relevant domains of the CDM. The competencies, though particularly being erratic in sequential order concerning the levels of importance, draw more even and lucid pattern when classified as compounds. Hence, taken as a whole, it seems that the major stress is laid on leadership and technical domains. The following domains regarding the consecutive levels of importance were interpersonal, conceptual/creative and finally administrative. From these all, it can be inferred valid for the case that recruiters mainly look for managers with leadership, technical and interpersonal competencies and that candidates those who bear the competencies falling into the five domains stated above have a greater change for being appointed to a management position in the hospitality industry of Turkey.

Finally, it can be proposed that stakeholders should consider the findings of this study in practical terms. For example, professionals could benefit them in the nomination process of candidates as managers. Particularly, academics and trainers, in the process of educating and training their pupils or setting, adjusting, altering and updating the curriculum. And candidates should strictly take the results into account when planning their careers or for improving their prowess and becoming successful in 
the Turkish hospitality industry. Last but not least, it can be postulated that besides the perceptions gap talked about frequently, it is also high time to contemplate the fact of "environmental gap" which is born of and nuanced by the application area competencies extracted from. It is a critical contingent factor that researches should specifically refrain from disregarding when investigating the issue.

\section{Limitations and further research}

This study based on a sequence of time aimed to examine the management competencies in the Turkish hospitality industry. The study employing a content analysis found out fourteen focal competencies by analyzing job ads for management vacancies of four and five-stars hotels. This study conducted in Turkey was a propaedeutic one. A myriad of further substantiating assiduous studies based on diverse methods should be carried out in the destination to scrutinize every aspect of the subject in its details and enlighten the dark sides. It is imperative to keep the issue up-to-date and hence conduct constant studies to help eliminating obsolete applications both in the industry and tourism education, and consequently meet the actual needs for a higher service quality.

\section{References}

Alexa, (2016). The top 500 sites on the web. Retrieved March 15, 2016, from http://www.alexa.com/topsites

Airey, D., Johnson, S. (1999). "The content of tourism degree courses in the UK", Tourism Management, No.20, 229-235.

Amoha, V. A., Baum, T. (1997). "Tourism education: policy versus practice", International Journal of Hospitality Management, Vol. 9, No.1, 5-12.

Ashley, R. A., Bach, S. A., Chesser, J. W., Ellis, E. T., Ford, R. C., Lebruto, S. M., Millman, A., Pizam, A., Quain, W. J. (1995). "A customer-based approach to hospitality education", Cornell Hotel and Restaurant Administration Quarterly, Vol.36, No.4, 74-79.

Auw, E. (2009). "Human capital capabilities and competitive advantage", International Review of Business Research Papers, Vol.5, No.5, 25-36.

Bardarova, S., Jakovlev, Z., Koteski, C. (2013). "Investment on human capital in tourism and hospitality with a specific reference of R. Macedonia", Journal of Process Management New Technologies International, Vol.1, No.4, 74-81.

Baum, T. (1990). "Competencies for hotel management: industry expectations of education", International Journal of Contemporary Hospitality Management, Vol.2, No.4, 13-18.

Baum, T. (1991). "Management trainees in the hotel industry: what do managers expect", Journal of European Industrial Training, Vol.15, No.2, 3-8.

Baum, T., Kokkranikal, J. (2005). Human Resource Management in Tourism. Inside L. Pender and R. Sharpley (eds.), The Management of Tourism (pp.85-101), Sage, Chennai.

Baum, T. (2012). "Human resource management in tourism: a small island perspective", International Journal of Culture Tourism and Hospitality Research, Vol.6, No.2, 124-132. 
Becherel, L., Cooper, C. (2002). "The impact of globalisation on human resource management in the tourism sector", Tourism Recreation Research, Vol.27, No.1, $1-12$.

Breiter, D., Dements, C. J. (1996). "Hospitality management curricula for 21 st century", Hospitality and Tourism Educator, Vol.8, No.1, 57-60.

Brophy, M., Kiely, T. (2002). “Competencies a new sector”, Journal of European Industrial Training, Vol.26, No.2, 165-176.

Brown, S. (2010). Likert scale examples for surveys, ANR program evaluation Iowa State University extension. Retrieved May 17, 2016, from http://www.extension.iastate.edu/ag/staff/info/likertscaleexamples.pdf

Buergermeister, J. (1983). "Assessment of the educational skills and competencies needed by beginning hospitality managers", Journal of Hospitality and Tourism Research, Vol.8, No.1, 38-53.

Cheng, A., Brown, A. (1998). "HRM strategies and labour turnover in the hotel industry: a comparative study of Australia and Singapore", The International Journal of Human Resource Management, Vol.9, No.1, 136-154.

Christou, E., Eaton, J. (2000). "Management competencies for graduate trainees", Annals of Tourism Research, Vol.27, No.4, 1058-1061.

Christou, E. (2002). "Revisiting competencies for hospitality management: contemporary views of the stakeholders", Journal of Hospitality and Tourism Education, Vol.14, No.1, 25-32.

Chung, K. Y. (2000). "Hotel management curriculum reform based on required competencies of hotel employees and career success in the hotel industry", Tourism Management, Vol.21, No.5, 473-487.

Cooper, C., Shepherd, R. (1997). "The relationship between tourism education and the tourism industry: implications for tourism education", Tourism Recreation Research, Vol.22, No.1, 34-47.

Cooper, C., Fletcher, J., Fyall, A., Gilbert, D., Wanhill, S. (2008). Tourism: Principles and Practice, Pearson FT Prentice Hall, Milan.

Cooper, D. R., Schindler, P. S. (2014). Business Research Methods, McGraw-Hill Irwin, New York.

Dale, C., Robinson, N. (2007). Strategic Imperatives for Tourism SMEs in Europe. Inside R. Thomas and M. Augustyn (eds.), Tourism in the New Europe: Perspectives on SME Policies and Practices (pp.48-59), Elsevier, The Netherlands.

Dunne, E., Bennett, N., Carre, C. (1997). "Higher education: core skills in a learning society", Journal of Education Policy, Vol.12, No.6, 511-525.

Edgel, D. L., Allen, M. D., Swanson, J., Smith, G. (2014). Tourism Policy and Planning: Yesterday Today and Tomorrow, Routledge, Croydon.

Evans, J. (1993). "Tourism graduates: a case of over-production", Tourism Management, Vol.14, No.4, 243-246.

Hall, C. M. (2005). The Role of Government in the Management of Tourism: the Public Sector and Tourism. Inside L. Pender and R. Sharpley (eds.), The Management of Tourism (pp.217-231), Sage, Chennai. 
Hall, C. M., Valentin, A. (2005). Content Analysis. Inside B. W. Richie, P. Burns and C. Palmer (eds.), Tourism Research Methods: Integrating Theory with Practice (pp.191-210), Cabi, King's Lynn.

Hong, W. (2008). Competitiveness in the Tourism Sector: a Comprehensive Approach from Economic and Management Points, Physica-Verlag, Heidelberg.

Jolliffe, L., Farnsworth, R. (2003). "Seasonality in tourism employment: human resource challenges", International Journal of Contemporary Hospitality Management, Vol.15, No.6, 312-316.

Kandampully, J., Suhartanto, D. (2000). "Customer Loyalty in the Hotel Industry: the Role of Customer Satisfaction and Image", International Journal of Contemporary Hospitality Management, Vol.12, No.6, 346-351.

Katz, R. L. (1955). "Skills of an effective administrator", Harward Business Review, Vol.33, 33-42.

Kay, C., Russette, J. (2000). "Hospitality-management competencies: identifying managers' essential skills", Cornell Hotel and Restaurant Administration Quarterly, Vol.41, No.2, 52-63.

Kay, C., Morkarz, E. (2004). "Knowledge skills and abilities for lodging management success", Cornell Hotel and Restaurant Administration Quarterly, Vol.45, No.3, 285-298.

Kusluvan, S., Kusluvan, Z. (2000). "Perceptions and attitudes of undergraduate tourism students towards working in the tourism industry in turkey", Tourism Management, No.21, 251-269.

Ladkin, A. (2005). Careers and Employment. Inside J. Tribe (ed.), An International Handbook of Tourism Education (pp.437-450), Elsevier, Oxford.

Lee-Ross, D., Pryce, J. (2010). Human Resources and Tourism Skills Culture and Industry, Channel View, Bristol.

Lepak, D. P., Snell, S. A. (1999). "The human resource architecture: toward a theory of human capital allocation and development", The Academy of Management Review, Vol.24, No.1, 31-48.

Liu, A., Wall, G. (2006). "Planning tourism employment: a developing country perspective", Tourism Management, Vol.27, 159-170.

Mariampolski, A., Spears, M. C., Vaden, A. G. (1980). "What the restaurant manager needs to know: the consensus", The Cornell Hotel and Restaurant Administrative Quarterly, Vol.27, No.3, 77-81.

Millar, M., Mao, Z., Moreo, P. (2008). "Hospitality management educators vs. The industry: a competency assessment", Hospitality Management, Paper 6, http://repository.usfca.edu/hosp/6

Morris, C. O. (1973). "Job Competencies Expected of Hotel and Restaurant Administration Graduates with Implications for Curriculum Development", Oklahama State University Faculty of Graduate College, Master of Science.

Nankervis, A. R., Debrah, R. (1995). "Human resource management in hotels: a comparative study", Tourism Management, Vol.16, No.7, 507-513.

Nelson, A. A., Dopson, L. (2001). "Future of hotel education: required skills and knowledge for graduates of US hospitality programs beyond the year 2000 part one", Journal of Hospitality and Tourism Education, Vol.13, No.5, 58-67. 
Nickson, D. (2011). Human Resource Management for the Hospitality and Tourism Industries, Routledge, New York.

Nolan, C., Conway, E., Farrell, T., Monks, K. (2010). "Competency needs in Irish hotels: employer and graduate perspectives", Journal of European Industrial Training, Vol.34, No.5, 432-454.

Okeiyi, E., Finley, D., Postel, R. T. (1994). "Food and beverage management competencies: educator industry and student perspectives", Journal of Hospitality and Tourism Education, Vol.6, No.4, 37-40.

Petrova, P., Mason, P. (2004). "The value of tourism degrees: a Luton-based case study", Education and Training, Vol.46, No.3, 153-161.

Pfeffer, J. (1994). Competitive Advantage through People Unleashing the Power of the Work Force, Harvard Business School Press, United States.

Ployhart, R. E., Moliterno, T. P. (2011). "Emergence of the human capital resource: a multilevel model”, Academy of Management Review, Vol.36, No.1, 127-150.

Raybould, M., Wilkins, H. (2005). "Over qualified and under experienced: turning graduates into hospitality managers", International Journal of Contemporary Hospitality Management, Vol.17, No.3, 203-216.

Richardson, S. (2010). "Tourism and hospitality students' perceptions of a career in the industry: a comparison of domestic students and international students studying in Australia", Journal of Hospitality and Tourism Management, No.17, 1-17.

Roney, S. A., Oztin, P. (2007). "Career perceptions of undergraduate tourism students: a case study in Turkey", Journal of Hospitality Leisure Sport and Tourism Education, Vol. 6, No.1, 4-18.

Sandwith, P. (1993). "A hierarchy of management training requirements: the competency domain model”, Public Personnel Management, Vol.22, No.1, 43-62.

Sharpley, R. (2004). Sustainability: a Barrier to Tourism Development. Inside R. Sharpley and D. J. Telfer (eds.), Tourism and Development Concepts and Issues (pp.428-452), Channel View, Clevedon.

Su, A. Y., Miller, J. L., Shanklin, C. (1997). "Perceptions of industry professionals and program administrators about accreditation curriculum standards for hospitality programs", Journal of Hospitality and Tourism Education, Vol.9, No.4, 36-40.

Subramonian, H. (2008). "Competencies gap between education and employability stakes", TEAM Journal of Hospitality and Tourism, Vol.5, No.1, 45-60.

Thomas, R., Augustyn, M. (2007). Tourism in the New Europe Perspectives on SME Policies and Practices, Elsevier, The Netherlands.

Tas, R. F. (1988). "Teaching future managers", Cornell Hotel and Restaurant Administration Quarterly, Vol.29, No.2, 41-43.

Tsai, F. C., Goh, B. K., Huffman, L., Wu, C. K. (2006). “Competency assessment for entry-level lodging management trainees in Taiwan", The Chinese Economy, Vol.39, No.6, 49-69.

University of Cambridge. (2016). Driving success: human resources and sustainable development. Retrieved April 8, 2016, from http://www.cisl.cam.ac.uk/publications/publication-pdfs/hr briefing.pdf 
Valachis, I. (2003). Essential competencies for a hospitality management career: the role of hospitality management education. Retrieved May 10, 2016 from http://citeseerx.ist.psu.edu/viewdoc/download?doi=10.1.1.201.751\&rep=rep1\&ty pe $=$ pdf

Wang, J., Ayres, H., Huyton, J. (2009). "Job ready graduates: a tourism industry perspective", Journal of Hospitality and Tourism Management, Vol.16, 62-72.

Weber, R. P. (1990). Basic Content Analysis, Sage, United States.

Werner, J. M., DeSimone, R. L. (2012). Human Resource Development, SouthWestern, United States.

Wright, P. M., McMahan, G. C., McWilliams, A. (1994). "Human resources and sustained competitive advantage: a resource-based perspective", The International Journal of Human Resource Management, Vol.5, No.2, 301-326. 